\title{
Course and Program Assessment - Methodology for Continuous Improvement
}

\author{
Ramesh Narang \\ Department of Mechanical and Industrial Engineering Technology \\ Indiana University-Purdue University Fort Wayne
}

To meets the needs of accreditation and for continuous improvement, a methodology has been developed to assess the curriculum in the Department of Mechanical and Industrial Engineering Technology at Indiana University-Purdue University Fort Wayne.

The methodology consists of assessing the curriculum at two levels of operation, known as the course-level and the program-level of assessment. The course-level assessment consists of evaluating specific learning outcomes more frequently, with multiple measures of direct and indirect assessment. The program-level involves the assessment of more long-term effects of the teaching in the curriculum on student performance in their careers.

At the course-level assessment, the survey of students is focused on each learning outcome being taught and their feedback helps improve the teaching methodology in subsequent offering of the courses. To support this model of assessment and continuous improvement, a standard homework and test questions for each learning outcome have been developed. Any faculty, including part-time faculty, teaching a course have a standard teaching module to use for the course. Even though TAC of ABET does not require this level of detail for course assessment, it was considered it is better to get into greater detail initially and meet the needs of continuous improvement at both the program and course levels.

The paper describes the methodology using a typical theory and lab-oriented course in the Industrial Engineering Technology program. An example of a course assessment summary is shown that meets the needs of assessment and continuous improvement.

Even though the assessment and continuous improvement plan developed is applicable to any engineering technology program, this paper gives an example of the plan as applied to the A.S. degree program in Industrial Engineering Technology.

Program Objectives and Outcomes

The Industrial Engineering Technology program objectives are based on the program criteria for industrial engineering technology ${ }^{1}$ as established by the Institute of Industrial Engineers. They are consistent with the mission of the university, the mission of the school and the goals of the department. They are determined and periodically evaluated based on the needs of the constituencies served by the programs.

The following objectives ${ }^{2}$ were revised and approved by the Industrial Advisory Committee.

"Proceedings of the 2005 American Society for Engineering Education Annual Conference \& Exposition Copyright (C) 2005, American Society for Engineering Education” 
Prepare graduates with knowledge, technical, analytical, and managerial skills necessary to develop, implement, and improve integrated systems in manufacturing and service industry that include people, materials, equipment, information, and energy. They will learn to employ their knowledge and skills responsibly toward the local and global community in concordance with professional and ethical standards. Graduates will be prepared for both immediate employment and continuation into the BS program.

The program objectives are consistent with the mission of the university to offer high quality undergraduate programs that meet regional needs and the department mission to offer quality mechanical and industrial engineering technology programs that meet regional needs. This is demonstrated by the approval of the objectives by the department Industrial Advisory Committee which consists of representatives of regional industries which employ the graduates.

The following program outcomes ${ }^{2}$ were revised and approved by the Industrial Advisory Committee. The outcomes are demonstrated by the student in each course in the curriculum and measured by the program at time of graduation.

a. An appropriate mastery of the knowledge, techniques, skills and modern tools of industrial engineering technology.

a1. Technical expertise in quality, metrology, and SPC.

a2. Technical expertise in ergonomics, and work methods design.

a3. Technical expertise in facilities layout, and production planning and control.

a4. Technical expertise in CAD, engineering graphics, and GD\&T.

a5. Technical expertise in materials and processes, and basic machining.

b. An ability to apply current knowledge and adapt to emerging applications of mathematics, statistics, science, engineering and technology.

c. An ability to conduct, analyze and interpret experiments and apply experimental results to improve processes.

d. An ability to apply creativity in the design of systems, components or processes appropriate to program objectives.

e. An ability to function effectively on teams.

f. An ability to identify, analyze and solve technical problems.

g. An ability to communicate effectively.

h. A recognition of the need for, and an ability to engage in lifelong learning.

i. An ability to understand professional, ethical and social responsibilities.

j. A respect for diversity and knowledge of contemporary professional, societal and global issues.

k. A commitment to quality, timeliness, and continuous improvement.

Program outcome $a$ is based on and exceeds the outcomes specified in the program criteria ${ }^{1}$ for industrial engineering technology as established by the Institute of Industrial Engineers. Program outcomes $b-k$ are established based on Criterion 2 of The Criteria for Accrediting Engineering Technology Programs ${ }^{1}$.

The program outcomes lead to the achievement of the program objectives through an interdisciplinary curriculum having current technical content and relevance, which prepares the 
graduates with knowledge, problem solving ability and hands-on skills in the field of Industrial Engineering Technology. By successfully mastering the program outcomes, the students will develop presentation skills, in both written and oral forms, to effectively communicate within their specialty field; be able to integrate analytical theory and practice into effective design and application concepts; master the utilization of computers and technical software; and will be exposed to a spirit of professionalism with ethical and social responsibility. There is a relationship established between the program objectives and the program outcomes ${ }^{2}$.

Each course in the curriculum has established learning outcomes which are listed on the course syllabus along with their relationship to the program outcomes. The matrix table relating some of the courses in the curriculum to the specific program outcomes is shown in Table 1.

Table 1 Matrix Relating Each Course in the Curriculum to Program Outcomes.

\begin{tabular}{|c|c|c|c|c|c|c|c|c|c|c|c|c|c|c|c|}
\hline \multirow[t]{2}{*}{ Courses } & \multicolumn{15}{|c|}{ Program Outcomes } \\
\hline & a1. & $\mathrm{a} 2$. & a3. & $\mathrm{a} 4$ & a5. & b. & c. & d. & e. & f. & g. & h. & i. & $\mathrm{j}$. & $\mathrm{k}$. \\
\hline ETCS 101 & & & & & & $\mathrm{X}$ & $\mathrm{X}$ & $\mathrm{X}$ & $\mathrm{X}$ & & $\mathrm{X}$ & & $\mathrm{X}$ & $\mathrm{X}$ & $\mathrm{X}$ \\
\hline IET 105 & $\mathrm{X}$ & $\mathrm{X}$ & $\mathrm{X}$ & & & & & & & $\mathrm{X}$ & & $\mathrm{X}$ & $\mathrm{X}$ & $\mathrm{X}$ & $\mathrm{X}$ \\
\hline MET 104 & & & & $\mathrm{X}$ & & $\mathrm{X}$ & & $\mathrm{X}$ & & $\mathrm{X}$ & $\mathrm{X}$ & & & & $\mathrm{X}$ \\
\hline MET 106 & & & & & & $\mathrm{X}$ & $\mathrm{X}$ & & $\mathrm{X}$ & $\mathrm{X}$ & $X$ & & & & $\mathrm{X}$ \\
\hline MA 159 & & & & & & $\mathrm{X}$ & & & & $\mathrm{X}$ & & & & & $\mathrm{X}$ \\
\hline ENG W131 & & & & & & & & & & & $\mathrm{X}$ & & & & $\mathrm{X}$ \\
\hline IET 204 & $\mathrm{X}$ & & & & & $\mathrm{X}$ & $\mathrm{X}$ & & $\mathrm{X}$ & $\mathrm{X}$ & $\mathrm{X}$ & & & & $\bar{X}$ \\
\hline MET 180 & & & & & $\mathrm{X}$ & $\mathrm{X}$ & $\mathrm{X}$ & & & & $\mathrm{X}$ & & & & $\mathrm{X}$ \\
\hline PHYS 218 & & & & & & $\mathrm{X}$ & $\mathrm{X}$ & & & & & & & & $\mathrm{X}$ \\
\hline STAT 301 & & & & & & $\mathrm{X}$ & & & & $\mathrm{X}$ & & & & & $\mathrm{X}$ \\
\hline IET 224 & & & $\mathrm{X}$ & & & $\mathrm{X}$ & & & & $\mathrm{X}$ & & $\mathrm{X}$ & & & $\mathrm{X}$ \\
\hline IET 267 & & $\mathrm{X}$ & & & & $\mathrm{X}$ & & $\mathrm{X}$ & & $\mathrm{X}$ & $\mathrm{X}$ & & $\mathrm{X}$ & & $\mathrm{X}$ \\
\hline PHYS 219 & & & & & & $\mathrm{X}$ & $\mathrm{X}$ & & & & & & & & $X$ \\
\hline MET 223 & & & & $\mathrm{X}$ & & & & $\mathrm{X}$ & & $\mathrm{X}$ & $\mathrm{X}$ & $\mathrm{X}$ & $\mathrm{X}$ & $\mathrm{X}$ & $\mathrm{X}$ \\
\hline IET 367 & & $\mathrm{X}$ & & & & & $\mathrm{X}$ & $\mathrm{X}$ & $\mathrm{X}$ & $\mathrm{X}$ & $\mathrm{X}$ & & $X$ & & $\mathrm{X}$ \\
\hline IET 310 & & & $\mathrm{X}$ & & & $\mathrm{X}$ & $\mathrm{X}$ & $\mathrm{X}$ & $\mathrm{X}$ & $\mathrm{X}$ & $\mathrm{X}$ & $\mathrm{X}$ & $\mathrm{X}$ & $\mathrm{X}$ & $\mathrm{X}$ \\
\hline MET 335 & & & & & $\mathrm{X}$ & $\mathrm{X}$ & $\mathrm{X}$ & & & $\mathrm{X}$ & $\mathrm{X}$ & $\mathrm{X}$ & $\mathrm{X}$ & & $\mathrm{X}$ \\
\hline
\end{tabular}

The curriculum is reviewed for achievement of program outcomes by the department curriculum committee on a yearly basis and revised as recommended by stakeholders including the faculty, students, alumni, employers, and the industrial advisory committee.

Assessment and Evaluation

Figure 1 shows a flow chart of the responsibilities and the timing in the assessment and continuous improvement process at the course level, that is the inner loop of assessment. The individual faculty member teaching the course is responsible to collect the assessment data, summarize it, and present the course assessment summary and recommendations for changes if any to the curriculum committee through the chair. 
Figure 2 shows the assessment and continuous improvement process for the program outcomes and program objectives. The assessment results of each course and the overall student performance in the learning outcomes, and the relevant program outcomes are summarized along with the feedback from the program constituents. The cycle is completed by making appropriate changes where necessary to help improve the overall student learning of knowledge and skills.

\begin{tabular}{|c|c|}
\hline $\begin{array}{l}\text { At the end of each } \\
\text { course: } \\
\text { (1) Student } \\
\text { evaluation of the } \\
\text { course, (2) Student } \\
\text { assessment of } \\
\text { outcomes, (3) } \\
\text { Faculty's assessment } \\
\text { of student } \\
\text { performance of } \\
\text { outcomes, (4) } \\
\text { Faculty's assessment } \\
\text { of student knowledge } \\
\text { of prerequisite } \\
\text { material, (5) Faculty } \\
\text { assessment of lab } \\
\text { equipment. }\end{array}$ & $\begin{array}{l}\text { Faculty gives the } \\
\text { course assessment } \\
\text { summary, } \\
\text { recommendations } \\
\text { for course revisions, } \\
\text { and equipment } \\
\text { purchases to the } \\
\text { curriculum } \\
\text { committee through } \\
\text { chair. }\end{array}$ \\
\hline
\end{tabular}

Figure 1 The Assessment And Continuous Improvement At The Course Level.

\section{Course Assessment Summary}

Table 2 gives an example of a course assessment summary of IET 310 Plant Layout and Material Handling course taught in the Spring 2004.

It indicates the number of students who responded to the Learning Outcomes Survey in the lowest 3 scores of 5, 6, and 7 in the $0-10$ scale. There were 17 respondents out of a total of 18 .

The table also indicates the average percentage obtained by the class in homework, exam 1, exam 2, and the final exam (HW, E1, E2, and FE respectively). 
The last column "S/NS" gives satisfactory (S) or not satisfactory (NS) to each learning outcome as given by the instructor from the assessment data.

"Not satisfactory" remark only indicates that improvement is possible in increasing the overall student performance and the next course offering should implement the recommended changes to achieve higher overall student performance on these learning outcomes.

The recommended changes to the "NS" learning outcomes are discussed next and later summarized in Table 3 .

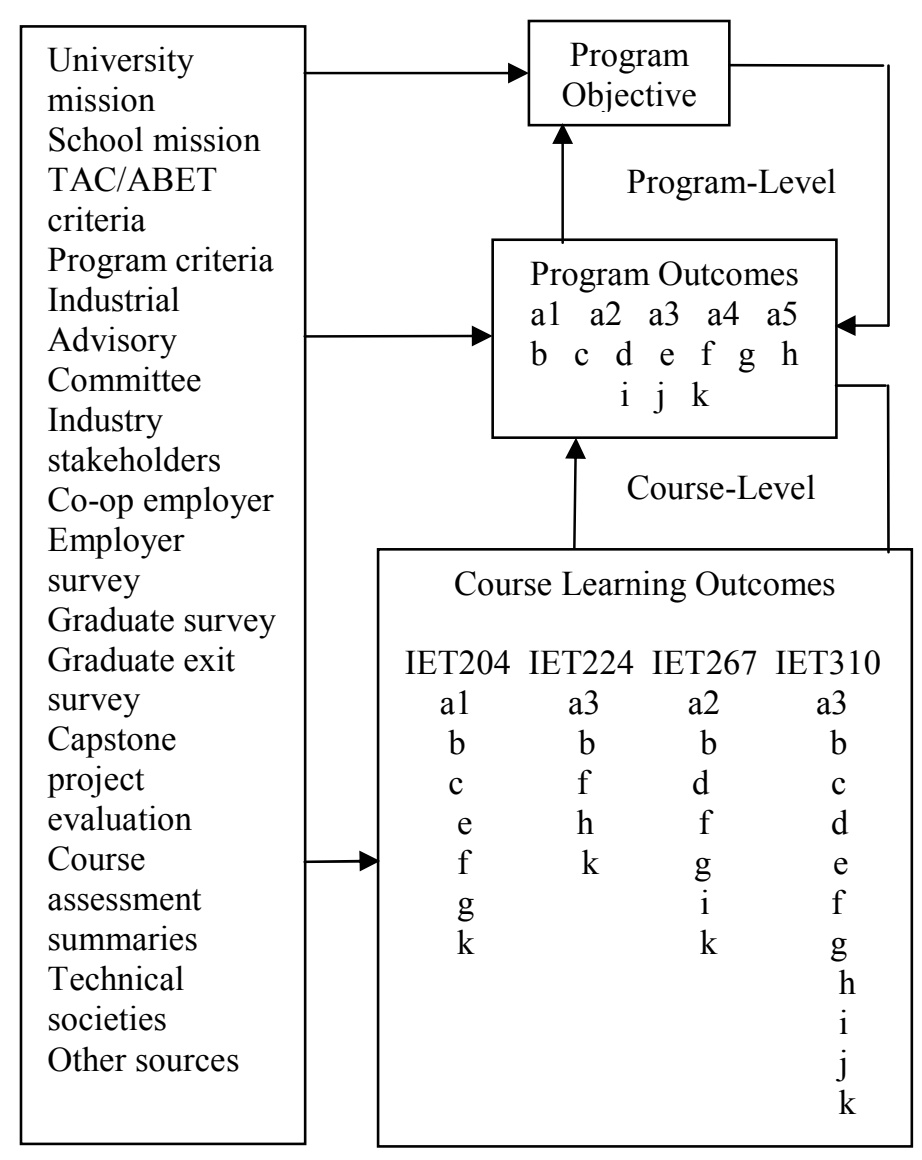

Figure 2 The Assessment And Continuous Improvement Process for Program Outcomes and Program Objectives.

Comments on "NS" Learning Outcomes

The learning outcomes that got "NS" in Table 2 are discussed below in the order of the outcome numbers. 


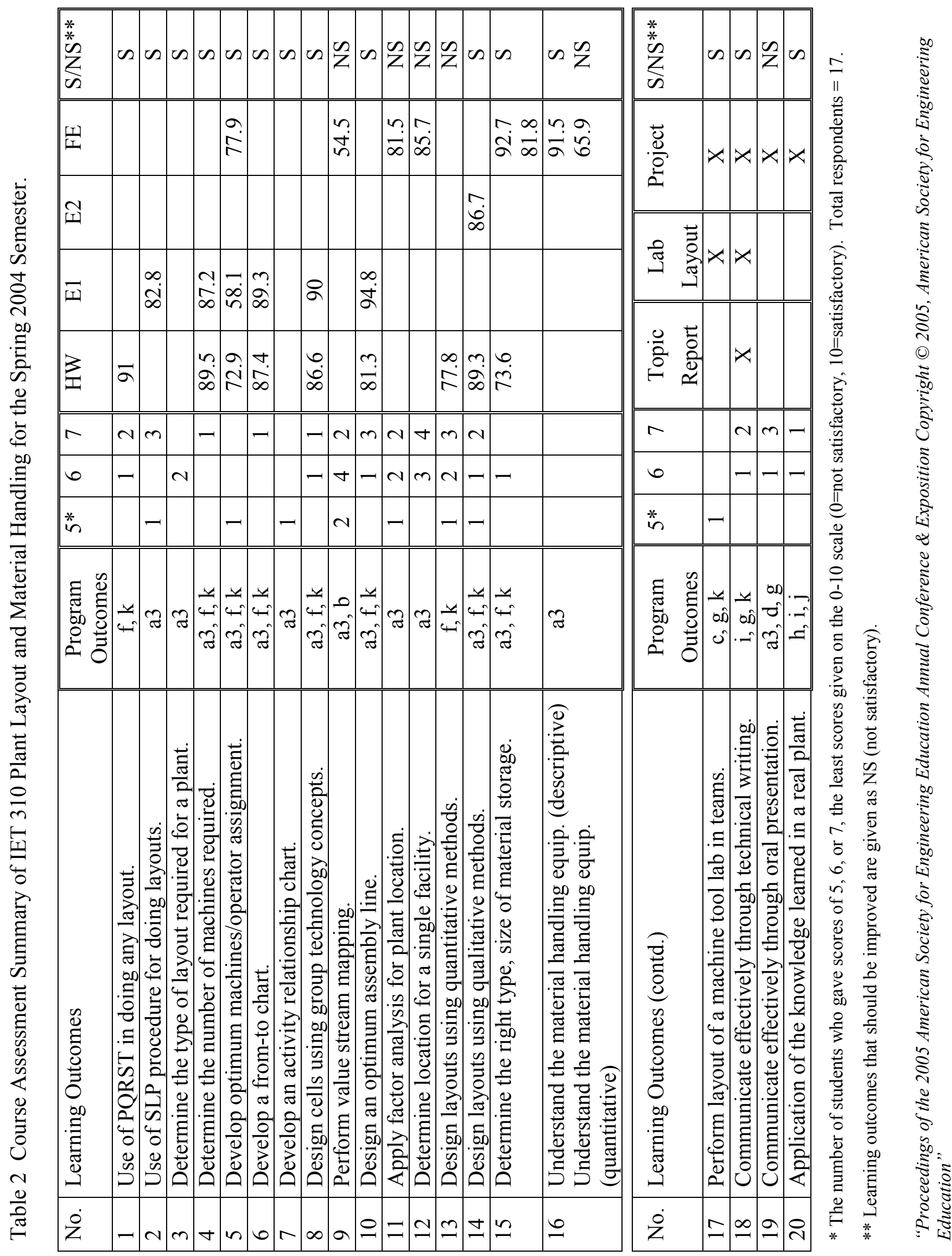


9. Perform value stream mapping.

Value stream mapping was newly introduced in this course. The book "Value Stream Management" by Tapping, Luyster and Shuker (Productivity Press, 2002) was kept in the library for reference. A solved example in the book was briefly done in the class and students were asked to refer to the book. No homework was given. According to the library sources, only 4 students out of 18 referred to the book during the semester.

From the results of student performance on other topics, it appears that they are able to solve or reproduce solution methods if they have done it or have been made to do it as homework. Assigning homework will also involve those students who miss a particular class but have homework to do. In the next offering of this course, this topic should have a homework assigned and more time should be given in class to solve a different example in detail.

11. Apply factor analysis for plant location.

No homework was given on this topic, but an example was done in class. The higher class average percentage obtained by the students on the final exam than the value stream mapping question shows that students know how to do it but have not clearly understood the concept. A short homework should be given on this topic for them to understand the concept and can refer to it for review at a later date.

12. Determine location for a single facility.

This also has similar reasons as given in (11) above. This topic is covered in detail in the text book and an example was done in the class, but again no home work was assigned. But more students (total 7) have responded that they did not understand this learning outcome. The reason for this may be that this topic was not given as much time as compared to other topics in the class. A simple homework on this topic that clears the basic concept should help the students but the class time can remain the same.

13. Design layouts using quantitative methods.

Apparently the connection was not made that quantitative methods refer to from-to chart and load-distance matrix multiplication on which they had homework to do in each case. The title of the handouts and homework did not refer to them as quantitative techniques. Also no question on this topic was asked in the exams. The students had a greater time gap to remember what was done when they filled the survey. A question on this topic in exam 2 should improve their performance.

16. Understand the material handling equipment (quantitative).

The original learning outcome was divided into descriptive and quantitative when the student performance was found to be poor in the final exam question. This topic was done 2 weeks before the finals week, and students apparently did not consider this to be an important topic to review before the exams. Even though no homework was assigned on this, there is no need to have one. However, this learning outcome will be separately monitored and evaluated after the results of the next course.

19. Communicate effectively through oral presentation.

"Proceedings of the 2005 American Society for Engineering Education Annual Conference \& Exposition Copyright (C) 2005, American Society for Engineering Education”" 
Four student groups presented their projects in one class session of total 75 minutes. Two of the company managers were also present during that time and they were giving their feedback to the students after each presentation. Each group had a leader assigned who had the full responsibility of getting the project done in time through their assigned students. The group sizes were based on the extent of the work involved in each project as indicated by the company.

These groups were assigned specific and distinct sections of the plant, and the groups were called by light metal, medium metal, heavy metal, and radiator guards groups. One large section of the plant was assigned a bigger group size of six students. The group leader of this group gave the entire presentation probably to cover the material in the given time, and the other five students did not speak.

The company managers later suggested that all students should be given the opportunity to speak. Their suggestion is well taken and in future presentations, specific reference will be made in the course outline itself to this effect: "For students working on group projects, the group project presentation should be shared by each student in the group."

Additional changes that would make the course assessment more effective:

(1) Remove the following learning outcomes: 3.

Table 3 Learning Outcomes for the Next Offering of IET 310 in Spring 2005.

\begin{tabular}{|c|c|c|}
\hline No. & Learning Outcomes & Assessment Method \\
\hline 1 & Use of PQRST in doing any layout. & HW \\
\hline 2 & Use of SLP procedure for doing layouts. & E1 \\
\hline 3 & Determine the number of machines required. & HW, E1 \\
\hline 4 & Develop optimum machines/operator assignment. & $\mathrm{HW}, \mathrm{E} 1, \mathrm{FE}$ \\
\hline 5 & Develop a from-to chart. & $\mathrm{HW}, \mathrm{E} 1$ \\
\hline 6 & Develop an activity relationship chart. & \\
\hline 7 & Design cells using group technology concepts. & HW, E1 \\
\hline 8 & Perform value stream mapping. & $\mathrm{HW}, \mathrm{FE}$ \\
\hline 9 & Design an optimum assembly line. & HW, E1 \\
\hline 10 & Apply factor analysis for plant location. & $\mathrm{HW}, \mathrm{FE}$ \\
\hline 11 & Determine location for a single facility. & $\mathrm{HW}, \mathrm{FE}$ \\
\hline 12 & Design layouts using quantitative methods. & HW, E2 \\
\hline 13 & Design layouts using qualitative methods. & $\mathrm{HW}, \mathrm{E} 2$ \\
\hline 14 & Determine the right type, size of material storage. & FE \\
\hline 15 & $\begin{array}{l}\text { Understand the material handling equip. (descriptive) } \\
\text { Understand the material handling equip. (quantitative) }\end{array}$ & $\begin{array}{l}\mathrm{FE} \\
\mathrm{FE}\end{array}$ \\
\hline 16 & Perform layout of a machine tool lab in teams. & Lab report \\
\hline 17 & Communicate effectively through technical writing. & $\begin{array}{l}\text { Topic and project } \\
\text { reports }\end{array}$ \\
\hline 18 & Communicate effectively through oral presentation. & Project report \\
\hline 19 & Application of the knowledge learned in a real plant. & Project report \\
\hline
\end{tabular}




\section{Results and Conclusions}

The current assessment plan has worked successfully to satisfy the needs of the program for continuous improvement and also meeting the TAC/ABET criteria. However, the amount of time and effort spent on the course assessment summary and its evaluation is tedious and needs to be simplified but still retain the depth and the value of assessment for continuous improvement.

The other part of the program assessment that needs to be further reviewed is that the program objectives need to be measured to show that the program is meeting the established objectives as documented in the plan. This process will take longer time to assess and evaluate since major part of the data should come from the graduates who are employed for at least a few years to be able to give a meaningful feedback for program improvement.

\section{Bibliography}

1. Technology Accreditation Commission of Accreditation Board for Engineering and Technology, Inc., Baltimore, MD, Criteria for Accrediting Engineering Technology Programs, Effective for Evaluations during 2004-2005 accreditation cycle. See www.abet.org/images/Criteria/T001\%200405\%20TAC\%20Criteria\%201-19-04.pdf

2. Indiana University-Purdue University Fort Wayne, Assessment and Continuous Plan for Manufacturing Technology Department, effective spring 2004. See www.mft.ipfw.edu/\#assess

\section{Biography}

RAMESH NARANG is an Associate Professor of Industrial Engineering Technology program in the Department of Mechanical and Industrial Engineering Technology at Indiana University-Purdue University Fort Wayne, at Fort Wayne, IN. He has received both his M.S. and Ph.D. in Industrial Engineering from the University of Iowa, Iowa City, IA in 1975 and 1992. His research interests include: automated feature recognition, lean manufacturing, ergonomics, cellular manufacturing, and statistical process control. 